\title{
Talaq-I-Tafwid And Its Application In Context Of Bangladesh: An Analytical Approach
}

\author{
Sufia Khanam \\ Lecturer, Department of Law \\ International Islamic University Chittagong, Bangladesh.
}

\begin{abstract}
Allah always discourages divorce and encourages the continuation of marriage. But now a day's rate of divorce is increasing day by day. In Bangladesh the patriarchal capitalism puts women in such a position within their communities that they always remain subordinate to male domination and in many cases this is reflected through domestic violence. Many women who are victimized by their husband or member of house in laws they thought divorce is the only solution to protect them.

Though in shariah husband has unfettered right to divorce his wife but now a days this trend is changed. Now divorce is increasingly initiated by women. With such dramatic change in divorce attitudes the question of what the driving forces are lead women to initiate divorce more than men in such a restricted patriarchal society as Bangladesh arise. Does this indicate that they achieve a better life by so doing? This question requires empirical inquiry and therefore, the women initiated divorce is the thematic focus of this article. This article focuses on women's own divorce narratives in order to explore their own perception and reasoning behind initiating their divorce.
\end{abstract}

KEY WORDS: Marriage, Talaq, delegate, Muslim, spouse, Divorcee.

\section{INTRODUCTION}

The very object of marriage is to represent a society. It is the most important social arrangements and the basis of social relationship. But in different situations this sacred relationship of the husband and wife becomes burden. It is the duty of the husband and wife to make the sacrosanct and heavenly relationship everlasting by their amiable and pleasant understanding. Emotions have power over the human nature. Since the opposite side of love is hatred, so, when love is blown away then dissolution is the only solution to get rid of the unbearable mental depression.The negative aspect of marriage is divorce. .The prophet (PBUH) declared that "With Allah, the most detestable of all things is divorce" ${ }^{11}$. In Muhammadan law, the absolute power to divorce is in the hand of the husband. And the unrestricted use of this power by the husband brings unbearable torment and affliction for the wife. In this situation the exploited and subjugated wife should liberate herself and secured herself by exercising delegated power of divorce.No system of law can produce marital happiness, but humane laws may at least alleviate sufferings and when marital life is wrecked, the home utterly broken by misunderstanding, jealousy, cruelty or infidelity, what greater boon can a wife have than the power to secure her liberty? ${ }^{2}$ In these circumstances talaq-i-tafwid is a sharp sword to prevent the arbitrariness of husband.

\subsection{DEFINITION}

Talaq-i-tafwid is constituted of two words. Talaq and Tafwid. The word 'Talaq' means repudiation. It comes from a root 'tallaqa' which means 'to release (an animal) from its tether, whence to repudiate the wife or free her from the bondage of marriage. In law, it signifies the absolute power which the husband possesses of divorcing his wife at all times. ${ }^{3}$ The word 'Tafwid' is derived from root word'fawod'which means to delegate. When the husband delegates his power of divorce to the wife herself or to a third person this is called talaq-etafwid. This delegation may be absolutely or conditionally and it may be for once only or for a time for permanently. ${ }^{4}$

Mulla quoted that "Talaq-e-tafwid" is one of the most important forms of divorce because it gives the Muslim women a right to divorce or dissolve their marriage without going to the court of law. Although the power to give divorce belongs primarily to the husband, he may delegate the power to the wife or to third person"s. So,

\footnotetext{
${ }^{1}$ Muhammad Ali, Manual of Hadith, p.284 (N.D), Dr.Md.faiz-ud-din, p.107.

${ }^{2}$ The Muslim wife's right of dissolving her marriage in (1936)38 Bom. Law Rep; JI 113,123.

${ }^{3}$ A.A.A Fyzee, Outlines of mohammadan law,p-150

${ }^{4}$ PLD 1963 Dhaka 602

${ }^{5}$ Mulla,Principles of Mohamedan law,p-236.
} 
this form of delegated divorce is perhaps the most potent weapon in the hands of a Muslim wife to obtain her freedom without the intervention of any court. ${ }^{6}$

Talaq-e-tafwid is a safeguard to a wife against hasty, ill-considered, arbitrary, tyrannical and unjustified divorce practiced by the husband.

In Baffatu bibi v. s.k. Abdur salim ${ }^{7}$ it was held that husband authorizes the wife to divorce in case of second marriage without prior permission from the first wife. It was cautioned that mere happening of contingency is not sufficient; the wife must clearly exerciser her option after the event has occurred.

\subsubsection{Talaq-i-tafwid in reasoned supposition:}

Either before or at the time of marriage even after the nuptial contract a Muslim wife can demand that she will have the right to divorce herself if her husband performs certain acts. Such acts may include, for example, if the husband becomes polygamous, she will automatically be conferred the right to dissolve the marriage contract. Startlingly, there is little disagreement amongst Sunni Muslim jurists in relation to the pre requisites of talaq-i-tafwid. ${ }^{8}$ The majority of learned Islamic scholars (including all Sunni Schools of thought with the exception of Ibn Hazm) agree that such provisions are valid, bind and irrevocable. Most Sunni jurists interpret the Quranic verse" O Prophet (PBUH)! Say to your wives: If you desire the life of this world, and its glitter, then come! I will make a provision for you and set you free in a handsome manner ${ }^{9}$ to mean that a woman can be delegated the right of divorce and she may exercise it at her discretion. Mean while others construe the above verse in its literal meaning, which does not devolve the power of divorce to a woman but instead, gives her the "Option "since it mentions that if they (the Holy Prophet's wives) do not want to live with him (PBUH), he could divorce them. ${ }^{10}$ This view is supported by another Quranic verse: The Quran describes the man controlling the marriage tie which implies that 'he may release it' by exercising the right of divorce. ${ }^{11}$ This verse was revealed when the Prophet (PBUH) told her"O, Aysha! I m going to mention to you something but you should not make a hasty decision until you consult your parents "and then He narrated this verse. Qurtubi, the great commentator of the holy quraan favors this opinion by detailing the Maliki schools of thought's exegesis. ${ }^{12}$ In his opinion when a woman exercises her delegated right of divorce it is considered like the third of the pronouncements of talaq because the word tasrih in the verse literally translated, means the third repudiation. Now when the wife exercises her right to divorce herself the resulting talaq will be either revocable (raaji) or irrevocable (bain) depending on the intention of the husband and the words of delegation used by him. In the Hanafi texts the general principle is that an explicit talaq is revocable, while one in ambiguous words is irrevocable. ${ }^{13}$ If the husband says to his wife "your business is in your hands "it conveys the meaning of talaq metaphorically and will be one irrevocable talaq (if the wife exercises her delegated authority. ${ }^{14}$

Quraanic obligation about women initiated divorce: The holy Quran is the master key of all problems of mankind. But in the holy Quran there is no concept as the "delegation of the right of divorce". According to Quran, where both parties in marriage have a natural right to divorce, there is no need to delegate the power of divorce to wife specifically. A woman is one of two parties in marriage. If she is major, she does not need to be represented by her father or anyone. She can divorce her husband whenever she wishes without any impediment. Women are not different to Allah (swt) than men in terms of human rights and responsibilities. The glorified Allah commands" (...) Women have equivalent rights and responsibilities (in marriage) according to the acceptable terms". ${ }^{15} \mathrm{~A}$ woman who is assumed about the continuation of her marital relationship, according to Quranic injunction she should inform the matter to the authorities that means to the law court or in the absence of law court the arbitrator. Understanding the situation if the law court permit the woman to divorce her husband only then she can divorce her husband by giving him back what she received as Mahr. It may be entire amount of Mahr or specific part of it. The amount to be paid back shall be decided by the authorities or arbitrators. If the husband is decided to be not guilty and to have fulfilled his all responsibilities as a husband, the wife is supposed give back the whole amount. In this regard Allah the almighty says:"...It is not lawful for you to take anything of what you have given them unless they both worry that they will not be able to keep within the limits of Allah. If you worry that they will not be able to keep within the limits of Allah, there is no

\footnotetext{
${ }^{6}$ A.A.A Fyzee, Outlines of mohammadan law,p-158-159.

${ }^{7}$ AIR (1950)Cal 304.

${ }^{8}$ Baillie,Digest,p-238

${ }^{9}$ Quraan,verse, 33:28

10Ibn Hajor, Fath-al-Bari,Vol.9,p.303

11 Quraan, verse, 2:237

12 Qurtubi, Ahkam al-Quraan,Vol,7,P-111

13 (Kasani, Badai,Vol,3,P-187

14 (Kasani,Badai,Vol.3,p-187

15 Al Quran, verse2:228.
} 
blame upon them if she sets herself free by giving back what she received...." ${ }^{16}$ So, the verses of the holy Quran have given the woman right to divorce and it is not conflicting to statutory law . It is notable that, the wife does not divorce her husband in talaq - $\mathrm{i}$ - tafwid and she cannot do this under Muslim Law but she only divorce herself on behalf of the husband under his delegated power. According to Muslim Law, when under the marriage contract the wife is empowered to divorce herself in specific contingencies which she exercises at the happening to any of them, the divorce will take effect to the same extent, as if it has been pronounced by the husband. So, It does not require any declaration from a court of law or Arbitration council. So, the wife will not lose her exclusive right to get full dower and maintenance for iddat period.

\subsubsection{Statutory law on talaq-i-tafwid:}

When women are failed to survive with dignity then it is essential to ensure this potent right of Muslim women by enacting law. 'The Dissolution of Muslim marriage act-1939'was the first effort. Then second attempt was taken in 1961 by enacting 'The Muslim Family Law Ordinance-1961.By this ordinance talaq-itafwid has given statutory recognition. Section 8 of MFLO refers to talaq-i-tafwid.Besides it section 18 of the Nikahnama provides that 'whether the husband has delegated the power of divorce to his wife". Section 8 of MFLO states that where the right to divorce has been duly delegated to the wife and she wishes to exercise the right or where any of the parties to a marriage wishes to dissolve the marriage otherwise than by talaq the provisions of section 7 of MFLO shall mutatis mutandis and so far as applicable, apply. ${ }^{17}$ Thus where a wife wants to exercise her right to dissolve the marriage under talaq-i-tafwid, she is required to give a notice to the Chairman in writing and send a copy of the same to the husband after the pronouncement of talaq.The Chairman must constitute an Arbitration Council within 30 days of the receipt of such notice by the wife for the purpose of bringing about reconciliation between the parties. ${ }^{18}$ It is important to note that under section 8 , like section 7 , no intervening marriage is required but talaq can be revoked. Lastly under the MFLO, divorce under section 8 will not be effective until the expiration of 90 days whether the marriage is consummated or not. ${ }^{19}$ Islamic law however considers divorce as effective instantaneously when the marriage is not consummated.

\subsubsection{Legal and rational conditions of talaq-i-tafwid:}

A stipulation that under certain specified conditions, the wife can pronounce divorce upon herself has been held to be valid, provided first, that

1. The option is not absolute and unconditional.

2. The conditions are reasonable and not opposed to public policy.

E. Tyan, mentions the interesting case of Salma bint 'Amir-al-Najjari who never married unless the husband promised her the right to divorce herself. ${ }^{20}$ The following conditions were held to be valid and reasonable, and where there was an agreement that the wife would have the power to divorce herself if they were not fulfilled, it was held to be binding on the parties: ${ }^{21}$

a) The husband should live a respectable life and should earn and his livelihood. He should maintain his wife and should live in a house approved by her.

b) The husband should not beat or ill-treat his wife and if he oppresses her wrongfully she will be entitled to reside at her father's house and realize a maintenance charge from him.

c) The husband should allow his wife to be taken to her father's house 4 times a year or that if the wife be in need of going to and coming back from her father's residence he would send her there and bring her back at his own expense.

d) The husband would not contract a second marriage without the consent of his wife unless she is either barren or perpetually ill.

e) The husband should pay her dower on demand and that the husband would not take any remission of dower from the wife except in the presence of her relations. Besides these a wife can divorce her husband by exercising her delegated right to divorce for the failure of husband to perform marital obligations.

The wife exercising her power under the agreement must establish that the conditions entitling her to exercise the power have been fulfilled. In such cases, the mere happening of the contingency is not sufficient, the wife must clearly establish first that events entitling to exercise her option have occurred, and secondly, that she actually exercised her option. ${ }^{22}$

\subsubsection{Various steps of delegation:}

16Al Quran, verse2:229.

17Section 8,Muslim Family Law Ordinance-1961

18 Section 7, Muslim Family Law Ordinance-1961

19 Section 7(6), , Muslim Family Law Ordinance-1961

20 A.A.A .FYZEE, Outlines of Muhammadan law. Page 159.

21 Shaukat Mahmood, principles and digest of Muslim law, pp.68-69

${ }^{22}$ A.A.A .FYZEE, Outlines of Muhammadan law. Page 159 
A man can delegate power to divorce to his wife at different stages and different times. In summary, there are three situations here: a) If the delegation (tafwid) took place after the spouses had entered into wedlock, and then this, without doubt, can be done. However, the husband here will be free to accept such conditions, as he is already in the marriage. b) The second situation is when this delegation (tafwid) takes place at the time of contracting the marriage. This is also permissible and valid, provided one condition is met, which is that the offer of marriage is initiated by woman coupled with the demand for tafwid, and the man accepts this. If the opposite takes place, it will be void. c) The third situation of Tafwid is when it takes place before the actual contract of marriage. In other words, the woman demands for the right to divorce herself if they are to get married. This is also permissible and valid. But also subject to one condition, that the husband attributes the Tafwid to the marriage. However, if the man did not attribute this to the marriage it will be void. It is stated in Durr al-Mukhtar: The condition of its validity is having ownership (by actual marriage) or referring it to the marriage such as he says: If I marry you, then you are divorced (or you have the right to divorce yourself). ${ }^{23}$

\subsection{Whether delegated divorce is revocable or not? :}

If the power of divorce is once delegated willfully by the husband to his wife, it is not revocable. The question here is of the power of the husband to revoke the talaq pronounced by the recipient of that authority. It is probably not without significance that the examples found in the Hanafi texts of delegations of authority to pronounce talaq made at the time of marriage(i.e., in the actual exchange of consents) and in pre -and post marital contracts , which refers to placing the business of the wife in her hands. The significance of this is that the talaq pronounced exercising the delegated power is irrevocable. Interestingly, Maliki texts explicitly declare that talaq-i-tafwid, pronounced by a wife empowered so to act by her marriage contract and whose marriage has been consummated, results in an irrevocable talaq. ${ }^{24}$

Tremendous application of delegated divorce in Bangladesh: Now a day's women are more and more aware about their rights which the law of the country offering them. They are not agreeing to remit any single right from their social, political, economic and religious rights. Most of the well educated do not tolerate anything which affects their self esteem and dignity. They make decision speedily when they feel extreme difficulty in living with husband.So,in practice we see that more of the 70 percent divorce is initiated by women, particularly by women of elite classes and highly qualified women, who have brought a radical change at their mentality that in case of maladjustment no need to continue old relationship. It should be buried and new life, new hope should be started. They face no problem after divorce but middle class and lower class women face multiple problems after divorce.

\subsection{Practical problems leading to delegated divorce in modern days:}

Reasons for and natures of divorce are varied among people, but lack of satisfaction in marriage often ends in divorce. There are many other problems leading to marital disruptions and divorce. Such as:

\section{Maladjustment in sexual relations:}

The sexual relationship is important for a happy marital life, because it is not only individual's biological need; it is closely related with the emotional binding between husband and wife. ${ }^{25}$ Therefore, the sexual relationship with its emotional strength plays a vital role in making a happy married life. Maladjustment of sexual relations with husband often causes emotional damage of the wife. And ultimately the wife exercises her delegated power of divorce.

\section{Infertility of the husband:}

Infertility of the husband is widely known as a reason of marital disruption and divorce in Bangladesh. Motherhood is the inherent demand of every wife. When the wives are disappointed perpetually from this expectation, it leads them to lose interests in their marriage relations with their husband.

\section{Extra marital or pre marital affairs of the husband:}

Every wife wants a happy conjugal life. She wants that, her husband will be dedicated only to her. When a husband involves to extra marital affairs or when wife comes to know about her husband's pre marital relationship, it makes the wife having dignity of life and personality to feel betrayed, which adversely affects the marital bond.

\section{Economic deficiency of husband:}

\footnotetext{
${ }^{23}$ RADD AL-Mukhtar ala al-durr, 3/344\& al-Ikhtiyar,2/170.

${ }^{24}$ F.H. Ruxton, Maliki Law: Being a Summary from the French Translation of the Mukhtasar of Sidi Khalil (London: 1916; reprinted Westpoint, Conn.: Hyperion Press, 1980), p. 131. A.D. Russell and A.A. Suhrawardy, A Manual of the Law of Marriage from the Mukhtsar of Sidikhalil (reprinted Lahore: Law Publishing Co., n.d.), p. 200

${ }^{25}$ Pothen, S. (1986).Divorce: its causes and consequences in Hindu society.
} 
Sometimes financial crisis can be unimaginable for a wife. By the husband's failure in provider role many wives feel frustrated and it affects them economically and socially.so, they search for chances to change and do something better in life.

5. Torture for dowry:

Dowry is now regarded as a big traditional problem in marriage in Bangladesh. ${ }^{26}$ Dowry is like disease now days. In most of the delegated divorce it is seen that wives are blackmailed by their husbands to bring dowry from their parent's house. It is ok until they refuse to continue to bring money or other things, when they resist it, problem arise in their family. Their husbands expose them mental torture and very often physical torture. So, Wives want to get rid of these inhuman tortures by untying their marital tie.

\section{Lac of decision making power:}

Most of the husbands think themselves as the king of the family. They don't care of commendations of wives. They think, wives have incomplete brain. So, they can have no decision making power.Husbands's dominance and restrictions heightens tensions in wives marital lives. They become insulted, harassed and unhappy. For why they want to create a separate social identity.

\section{Alcohol and drug addiction:}

Addiction to any kind of drugs, prohibited drinks, illegal and unfair activities weakens the foundation of relationships. When a man is addicted to alcohol or drug he loses his sense. He forgets what to do and what should not to do. A drunkard husband is a curse for a wife. When the wife is failed by her thousands attempts to return back her husband to the true way, and then she realizes it's better to live alone.

\section{Domestic abuses:}

Domestic abuse is a wide spread practice in Bangladesh. ${ }^{27}$ Domestic abuse can be defined as mental, verbal and physical. And often lead to the deterioration of marital harmony. Many wive's consider their husband's verbal and mental abuse worse than the physical abuse to them. They are more traumatized by their husband's humiliation, accusation, mocking and criticisms in their everyday life, which make it impossible to continue their marriage.

\section{Infidelity of the husband:}

Relationship is based on faith and belief. When either of the partners betrays to others relationships do break up. Unfaithfulness is a harmful disease of matrimonial relationship. Disloyalty of husband comes the relationship to an end. And a wife never continue her marital life with a man of double standard.Beacause proverb goes that:"it is better to be alone than being with someone who makes you alone".

\section{Early marriage:}

Marriage at a very immature age increases threat of dissolution. Particularly, the child marriage.

\section{Communication gap:}

Absence of contact creates lot of gaps among couples .Such gaps lead to lot of misunderstanding between them. The 'ego 'stops them to be open up to one another If they don't speak for a longer time that stops two ways communication then there is a danger of ending their relationship.

\section{Boredom:}

Couples often get bored off from their monotonous lifystile. While compatible couples stay together at such times, some couples get disinterested, grow distantly and eventually fall apart.

\section{Childrearing:}

Child rearing is one of the sensitive issues causing rifts in the marriages and contributing as one of the major reasons for splitting or divorce .If the husband is totally reluctant towards child rearing issues, then the reason can be enough to provoke the petition of delegated divorce by the wife.

\section{Dissimilarity in anticipation and priorities:}

In this world it is not possible to find a life partner as one's expectation. There is variation in every person's thought because every one's way of life is different. Even their character and behavior is also separate. In some cases the expectation and demands of spouses are so divergent that they cannot way in the same way .So, they look for a new life.

\section{Lack of equality in the relationship:}

In Muslim marriage equality (kufu) should be maintained. Inequality in case of social status of husband and wife sometimes makes the relationship bitter.

\section{Aversion to relationship:}

\footnotetext{
${ }^{26}$ Ahmed, R. (1987). Changing Marriage Transactions and Rise of Demand System in Bangladesh. Economic and Political Weekly, 22(17), WS22-WS26. Retrieved from http://www.jstor.org/stable/pdfplus/4376957.pdf?acceptTC=true

27 Ameen, N. (2005). Wife Abuse in Bangladesh: An Unrecognized Offence. Dhaka: The University Press Limited. 
Aversion to relationship brings change in the intimacy department of the husband and wife. They look for better happiness and ultimately it turns to divorce.

\section{Lack of mediation:}

Sometimes husband and wife conceal their quarrel and misunderstanding between them. They do not share their problem with any other.For the lack of mediation they break up their relationship without hesitation. 18: husband's prohibition in wife's service:

Many dogmatic Bengali husbands do not like that their wife will go to the outside of home for service. On the other hand no well educated woman of Bangladesh wants to be her husband's burden. If the husband restricts in wife's personal liberty, then wife seek release from the bond of marriage.

\subsection{Legal causes or legal ground of talaq e tafwid:}

The dissolution of Muslim marriage act,1939 describe the ground for decree for dissolution of marriage .A women married under Muslim Law shall be entitled to obtain a decree for the dissolution of her marriage on only or more of the following grounds, namely:-

1) That the where about of the husband have not been known for a period of the four years;

2) That the husband neglected or has failed to provide for her maintenance for a period of two years;

2a) that the husband take $\mathrm{n}$ an additional wife in contravention of the provision of the Muslim Family Laws Ordinence.1961;

3) That the husband has been sentenced to imprisonment for a period of seven years or upwards;

4)) that the husband 4has failed to perform, without reasonable cause, his marital obligation for a period of three years;

5)) that the husband was impotent at the time of marriage and continues to be so;

6)) that the husband has been insane for a period of two years or is suffering from leprosy or a virulent disease;

7) That she ,having been given in marriage by her father or other guardian before she attain the age of [eighteen years], repudiated the marriage before attaining the age of [nineteen years]; provided that the marriage has not been consummated;

8) That the husband treats her with cruelty, that is to say,-

a)habitually assault her or makes her life miserable by cruelty of con duct even if such conduct does not amount to physical ill -treatment, or

b) Associates with women of evil repute or leads an infamous life, or

c) Attempts to force her to lead an immoral life, or

d) Disposes of her property or prevents her religious profession or practice, or

e) obstructs her in the observance of her religious profession or practice;

f) if he has more wives than one, does not treat her equitably in accordance with the injunctions of the Quran;

9) On any other ground which is recognized as valid for the dissolution of marriage under Muslim Law;

Provided that -

a) No degree shall be passed on ground (3) until the sentence has become final;

b) a degree passed on ground (1) shall not take effect for a period of six month from the date of such decree, and if the husband appears either in person or through an authorized agent with in that period and satisfies the court that he is prepared to perform his conjugal duties, the court shall set aside the said degree; and

c) before passing a decree on ground (5) the court shall, on application by the husband, make an order requiring the husband to satisfy the court within a period of one year from the dated of such order that he has ceased to be impotent, and if the husband so satisfied the court within such period, no decree shall be passed on the said ground. ${ }^{28}$

\subsection{CONSEQUENCES OF DELEGATED DIVORCE:}

Individuals enter into marriage with many dreams and expectations of making their own world. The collapse of these dreams by the termination of marriage may lead them into serious psychological crisis. Divorce may provide individuals with many positive changes;Nevertheless the negative consequences of divorce may be severe for them. In Bangladesh, divorce exposes both men and women to distress and stigma in their post divorce lives. But the consequences of divorce are more severe for women, across class, location, and socioeconomic conditions in the post-divorce period. ${ }^{29}$ It is said that divorce is the most detestable among all permitted things in the eye of Allah, yet Islam permits it to avoid more detestable consequences in the society. Divorce is necessary when there is no longer love, affection, faith or understanding between the spouses .Islam does not encourage continuation of unhappy and loveless marriages. However, talaq always brings bad impact

\footnotetext{
${ }^{28}$ The Dissolution of Muslim Marriage Act-1939

${ }^{29}$ bora.UIb.no/bitstream/handle/1956/5312/84856665.pdf?Sequence $=1$

DOI: 10.9790/0837-2107053441 $\quad$ www.iosrjournals.org $\quad 39 \mid$ Page
}


on human life. Mental depression is output of divorce. Spouses are become depressed. Marriage is the tie of love.So, after the breaking up conjugal life, spouses feel lonely. Separation and divorce is often associated with heart wrenching emotions, unspeakable sadness, depression, anxiety and much more. Most of the women are not solvent in our society. Before marriage, the women depend on parents. After marriage women depend on husband. But after dissolution, women cone become helpless and her maintenance and accommodation become uncertain. ${ }^{30}$ According to George Mason University sociology and law professor and author Lenore Weitzman, women are more likely to face damaging financial consequences and a diminished standard of living than their male counterpart."For divorced women maintenance should be provided on a reasonable (scale).This is a duty on the righteous" ${ }^{31}$ But most of the divorced women do not get their deserved maintenance. Divorced women get maintenance only for iddat period not more. But the decision of Shah Banu case was reversed by Hefzur Rahman v.Shamsun Nahar Begum and others ${ }^{32}$ Besides these sometimes the curse of delegated divorce may be more cruel to women. They are blamed and excluded by their social networks, and even sometimes by their family, because of the social stigma of divorce. Their decision to divorce makes society question their womanhood. They are treated as a different class (a defect class) by their relatives and social circle. Thereby, the women and their children are deprived of familial and social contact and belonging. To them, social life becomes embarrassing in many regards, despite their personal achievements. Thus, the social stigma of divorce imposes immense psychological costs on these women. They cannot resist the social sanctions imposed on them due to their divorce but have to accept them. ${ }^{33}$

Positive Impacts of Divorce on the woman:Although divorce increases the risk of negative outcomes for women, it also brings possibilities. They get back their liberty, freedom, decision making power, and self esteem. Most of the women involve themselves in job before divorce.So; they do not face any economic crisis. They also get financial support from their parent's house after divorce. Sometimes continuous quarrelling make the family into hell and it impact badly on children.childrens become otistic, hyper active, aggressive, young offender and unsocial. They suffer from depression, anxiety and other emotional disorders by realizing the bitter relationship between their parents. At this situation woman divorces her husband to give her children harmonious and secured upbringing.

\section{RECOMMENDATIONS}

Some suggestions are recommended to reduce the sufferings of women who exercise their delegated power to divorce.Though our laws have protected the women's right of delegated divorce like section 8 of the Muslim Family Law Ordinance 1961 and section 18 of Kabinnama but this is not implemented properly. Because woman of our country are unable to seek the legal protection due to lack of awareness, poverty, illiteracy and community opposition against such a movement.So, it is essential to make the women aware about their right. The challenge is then to educate women living in communities about their legal position and enable their access to law as well as to promote community awareness by accepting Islamic law and statutory law about talaq-itafwid. And for this campaign arising awareness among the women about their right should be introduced in every educational institution and society at large.Sometimes women are deprived from their right of delegated divorce for kazi ignorant of shariah law as well as existing statutory law.So, it is necessary to appoint well educated kazi, and make the legislation or amendment in the family laws that a person who solemnizes the marriage must be graduate and having the profound knowledge of Islam and statutory law. Muslim Family Law Ordinance 1961 and Family Court Ordinance 1985 are the notable effort to ensure the right of delegated divorce of women. All provisions regarding the procedure of the divorce has mentioned in these Ordinances but no provision has been mentioned regarding the procedure of the recovery of post divorce maintenance and due dower of the wife separated by divorce .It is almost as same as the provisions of Shariah law. So, radical change should be brought in the Muslim Family Law Ordinance to ensure the right of maintenance and due dower of Muslim women. After divorce women are harassed in our civil courts when they sue for their dower, maintenance and custody of children. So, the laws relating women's right to dower ,maintenance and custody of children should be effectively enforced and the Muslim women's these very rights should be ensured. For this clear criteria to guide the discretion of Family Court judges when determining post divorce maintenance amount should be developed. Any link between wife's post divorce maintenance and her obedience, chastity, marital duties or good character should be abolished.So; it is essential to review all Family Courts and appellate procedures and streamline them to minimize delays and the ability of the Family Court to settle the divorce, maintenance and dower related cases fairly and speedily should be increased. Until polygamy is completely eradicated, the humiliating condition of women will not be ended. During critical period after marital breakdown, the immediate access to social assistance of divorcee women should be ensured. The government

\footnotetext{
${ }^{30}$ www.bdresearchpublications.com/admin/journal/upload/1308118/1308118.pdf

${ }^{31} \mathrm{Al}$ quraan, verse 2:241.

3259 DLR(1999)ad, 172

${ }^{33}$ bora.Ulb.no/bitstream/handle/1956/5312/84856665.pdf?Sequence $=1$
}

DOI: 10.9790/0837-2107053441 $\quad$ www.iosrjournals.org $\quad 40 \mid$ Page


should ensure social and economic security of divorcee women by distributing khas land among them..In rural area many divorces are occurred for dowry. So, Dowry Prohibited Act should be implemented with strong hand and child marriage should be prevented by implementing the Child Marriage Restraint ACT 1929. Besides these, loss of morality of husband is a main reason for delegated divorce by wife.So; our morality should be developed by following the religious rules and regulations in every sphere of life. After all the patriarchal view of husbands should be changed. They should think that women are not their subordinate but women are their complementary. So, women should given their due respect.

\section{CONCLUSION}

Divorce is a social crime and it is one kind of social disease but in some cases it is beneficial to particular individual. Upcoming pleasure and cheerfulness of the spouses should not destroy by a hideous and nauseating companionship. That's why Quran permits divorce so that the spouses can take initiative to get rid of an odious union. After all, marriage is a civil contract which can be terminated by either party when it fails to serve its ultimate objectives.In ancient times husbands were used to divorce their wives when they wished but now a day this viewpoint is changed, where woman's rights are fully legislated. So, by implementing this right a wife can easily divorce her husband if he fails to fulfill the conditions. Wive's right of delegated divorce can be an effective deterrent against whimsical and irresponsible divorces by the husband. "It is better to be alone than being with someone who makes you alone".At last measures should be taken to change our patriarchal concept and effective awareness should be created among all women of the country about the obligations of the husband to his wife and children. .Otherwise the women will be wretched, depressed and dejected forever. 